\title{
SOSIALISASI MANFAAT DAN PEMBUATAN NATTO DAN SOY YOGURT MELALUI KEGIATAN WEBINAR DAN PRAKTIK
}

\author{
Oleh: \\ Sri Sumarsih, Afaf Baktir, Fatiha Khairunnisa, Muji Harsini, Aning Purwaningsih, Siti Wafiroh, Hartati, \\ Purkan, Sofijan Hadi
}

Departemen Kimia Fakultas Sains dan Teknologi Universitas Airlangga

sri-sumarsih@fst.unair.ac.id.

\begin{abstract}
Abstrak
Natto dan Soy Yogurt merupakan makanan produk fermentasi yang sangat bermanfaat untuk meningkatkan kesehatan. Kegiatan Pengabdian Kepada Masyarakat (PKM) ini bertujuan untuk sosialisasi manfaat dan pembuatan Natto dan Soy yogurt agar bisa diketahui masyarakat luas. Kegiatan PKM di masa pandemi Covid-19 tidak bisa dilaksanakan dengan tatap muka dan berkegiatan bersama-sama masyarakat dalam jumlah banyak. Oleh karena itu, kegiatan PKM dilaksanakan melalui kegiatan webinar dan praktik. Seminar online (webinar) dipilih agar cakupan lebih luas dan lebih banyak masyarakat yang berpatisipasi di masa pandemi. Tatap muka dan berkegiatan bersama masyarakat dilaksanakan dengan jumlah peserta terbatas, sesuai dengan protokol kesehatan. Tingkat keberhasilan, kemanfaatan dan keberterimaan masyarakat dari kegiatan PKM ini diketahui dari respon peserta selama mengikuti kegiatan. Berdasarkan respon peserta kegiatan, secara umum dapat disimpukan bahwa kegiatan PKM pada kondisi pandemi Covid-19 dapat terlaksana dengan baik melalui kegiatan webinar dan praktik. Aplikasi Zoom Meeting dapat digunakan sebagai media kegiatan PKM, walaupun belum bisa menjangkau lapisan masyarakat luas. Materi yang disampaikan Nara sumber sesuai untuk kondisi pandemi saat ini, mudah dipahami, mudah dipraktekkan dan dapat dikembangkan untuk usaha rumahan. Kegiatan ini diharapkan turut berperan dalam peningkatan keberdayaan masyarakat dalam mengolah kedelai menjadi makanan yang variatif dan mempunyai nilai tambah, baik gizi maupun khasiatnya. Selanjutnya dapat dikembangkan sebagai peluang usaha rumahan untuk mendapatkan penghasilan tambahan.
\end{abstract}

Kata Kunci: Sosialisasi, Natto, Soy Yogurt, Webinar, praktik

\begin{abstract}
Natto and Soy Yogurt are fermented food products that are very beneficial for improving health. This Community Service Activity aims to socialize the benefits and make Natto and Soy yogurt so that it can be known by the wider community. PKM activities during the Covid-19 pandemic cannot be carried out faceto-face and have activities with the community in large numbers. Therefore, Community Service activities are carried out through webinars and practical activities. The online seminar (Webinars) was chosen so that the coverage is wider and more people participate during the pandemic. Face-to-face meetings and activities with the community are carried out with a limited number of participants, in accordance with health protocols. The level of success, benefit and acceptance of the community from this Community Service activity is known from the responses of the participants during the activity. Based on the response of the activity participants, in general it can be concluded that Community Service activities during the Covid-19 pandemic can be carried out well through webinars and practical activities. The Zoom Meeting application can be used as a medium for Community Service activities, although it has not been able to reach the wider community. The material presented by the resource persons is appropriate for the current pandemic conditions, easy to understand, easy to practice and can be developed for home businesses. This activity is expected to play a role in increasing community empowerment in processing soybeans into food that is varied and has added value, both nutrition and usefulness. Furthermore, it can be developed as a home-based business opportunity to earn additional income.
\end{abstract}

Keywords: Socialization, natto, soy yogurt, webinar, practical

\section{PENDAHULUAN}

Kedelai merupakan bahan baku tahu dan tempe, makanan yang digemari masyarakat Indonesia. Kedelai memiliki kandungan protein yang cukup tinggi dan mengandung fitokimia seperti isoflavon, saponin dan fitosterols yang bermanfaat untuk meningkatkan kesehatan, seperti mencegah penyakit kardiovaskular, mengurangi gejala menopause, menurunkan berat badan, arthritis, diabetes, osteoporosis dan fungsi otak (Vij et al., 2011). Selain itu, kedelai juga dapat diolah menjadi Yogurt kedelai dan Natto. Makanan hasil fermentasi ini mempunyai banyak manfaat yang belum diketahui oleh orang Indonesia. Proses fermentasi dapat mengurangi antinutrisi, 
sehingga dapat meningkatkan asupan senyawa nabati yang bermanfaat bagi tubuh.

Natto adalah makanan khas orang Jepang, sebagai menu sarapan, teman makan nasi atau miso sup, yang kaya akan protein, vitamin dan mineral. Natto sangat bergizi dan mempunyai berbagai manfaat kesehatan, antara lain memperkuat tulang, jantung yang lebih sehat dan meningkatkan sistem kekebalan tubuh. Natto dibuat dari kedelai dengan teknik fermentasi menggunakan bakteri Bacillus subtilis var. natto, Natto mengandung enzim Nattokinase, amilase, lipase, selulase, katalase, sukrase, protease dan pirazin (Papp, 2014; Petre, 2017).

Pengolahan kedelai menjadi susu fermentasi dilakukan untuk memperoleh produk yang mempunyai nilai tambah dan masa simpan yang lebih lama. Yogurt kedelai (soy yogurt) merupakan salah satu makanan non hewani yang sangat baik bagi kesehatan, yang mengandung probiotik, mineral (kalsium dan fosfor) dan semua asam amino esensial yang diperlukan tubuh. Soy yogurt sangat bermanfaat untuk kesehatan, melindungi sistem gastrointestinal, serta berpotensi sebagai antioksidan, antikanker, antidiabet, antihipertensi, dan meningkatkan sistem imum (Vij et al., 2011).

Berdasarkan latar belakang di atas, Natto dan Soy Yogurt ini sangatlah tepat untuk diangkat sebagai topik pada program pengabdian kepada masyarakat di masa pandemi Covid-19, yang saat ini sedang melanda di hampir semua negara di dunia. Di masa pandemi ini, kita dituntut untuk selalu menjaga kesehatan dan mengonsumsi makanan yang bernutrisi tinggi. Namun demikian, kegiatan pengabdian kepada masyarakat di masa pandemi tidak bisa dilaksanakan dengan tatap muka langsung dan melakukan kegiatan bersamasama masyarakat dalam jumlah banyak. Kegiatan harus dilaksanakan sesuai dengan kondisi pandemi, dengan mempertimbangkan dan mematuhi protokol kesehatan yang sudah ditetapkan Pemerintah Indonesia dan WHO.

Oleh karena itu, kegiatan PKM dengan topik sosialisasi manfaat dan pembuatan natto dan Soy Yogurt kali ini dilaksanakan melalui kegiatan webinar dan praktik. Seminar online (Webinar) dipilih agar cakupan lebih luas dan lebih banyak masyarakat yang berpatisipasi di masa pandemi. Tatap muka dan berkegiatan bersama masyarakat dilaksanakan dengan jumlah peserta terbatas.

\section{METODE}

Kegiatan PKM dilaksanakan sesuai kondisi pandemi Covid-19 dengan mematuhi protokol kesehatan yang sudah ditetapkan Pemerintah Indonesia dan WHO. Kegiatan dilaksanakan dalam bentuk blended seminar online (webinar) dan praktik..

\section{Webinar

$\begin{array}{ll}\text { Sasaran } & \text { : Masyarakat umum } \\ \text { Jumlah Peserta } & \text { : tidak dibatasi } \\ \text { Media } & \text { : Zoom Meeting }\end{array}$

Sosialisasi kegiatan Webinar diawali dengan mengirimkan flyer Webinar melalui media sosial Whatsapp, baik grup maupun perorangan.

2. Kegiatan bersama masyarakat

Kegiatan ini dilaksanakan dengan mengumpulkan dan berkegiatan bersama masyarakat

Sasaran : Ibu-ibu PKK

Tempat : Balai RT 09 RW 07

Kelurahan Sawunggaling,

Kecamatan Wonokromo

Peserta : 15 orang

Acara

: 15 orang

a. Mengikuti Webinar bersama melalui layar

b. Praktik membuat dan menyajikan Natto dan Soy Yogurt

\section{Pembuatan Natto dan Soy Yogurt}

Natto dan Soy Yogurt dapat dibuat dengan mudah menggunakan peralatan dapur rumah tangga. Bahan mudah diperoleh di pasar/toko. sedangkan bibit Natto dan Yogurt dapat dibeli di toko online.

\section{Cara membuat Natto:}

a) Kedelai sebanyak 300 gram yang sudah dicuci bersih direndam selama 12 jam..

b) Kedelai yang sudah menggembung dicuci dengan air hingga bersih, kemudian dikukus dengan panci presto selama 40 menit. Jika dikukus menggunakan dandang biasa, waktunya lebih lama $( \pm 3$ jam).

c) Sambil menunggu pengukusan, disiapkan wadah/ mangkuk kaca/porselin (volume \pm 2 liter) dan sendok, kemudian direndam/dibilas dengan air panas agar steril.

d) Bibit natto 1 sachet $(0,3$ gram $)$ dimasukkan dalam gelas kecil dan ditambahkan 3 sendok air panas.

e) Kedelai kukus dalam keadaan masih panas, dimasukkan ke dalam wadah steril. Bibit natto segera ditambahkan dan diaduk-aduk menggunakan sendok hingga merata.

f) Wadah natto ditutup rapat dengan plastik wrap. Plastik ditusuk-tusuk dengan tusuk gigi. Selanjutnya disimpan di dalam tempat bertutup rapat selama 24 jam.

g) Natto yang sudah jadi disimpan di kulkas selama 2-7 hari, tergantung tingkat kematangan yang dikehendaki. Semakin lama penyimpanan, Natto semakin berlendir dan lengket.

h) Pada penyajiannya, natto dapat ditambahkan kecap, saus/ sambal sesuai selera. Natto dapat dikonsumsi bersama nasi dan lauk pauk.

i) Natto disimpan di freezer, dan dapat digunakan sebagai bibit pada pembuatan Natto selanjutnya. 


\section{Cara membuat Soy Yogurt:}

a) Kedelai sebanyak 200 gram yang sudah dicuci bersih direndam selama 12 jam hingga mengembang.

b) Kedelai dihilangkan kulit arinya dan dicuci dengan air hingga benar-benar bersih.

c) Kedelai diblender secara bertahap dengan penambahan air hingga 1 liter, kemudian disaring dengan kain bersih.

d) Susu kedelai yang diperoleh dipanaskan hingga mendidih, sambil diaduk-aduk.

e) Susu kedelai didinginkan hingga hangat (suhu $40^{\circ} \mathrm{C}$ ).

f) Bibit yogurt 1 sachet (5 gram) ditambahkan ke dalam $100 \mathrm{~mL}$ susu kedelai hangat dan diaduk merata, kemudian ditambahkan $900 \mathrm{~mL}$ susu kedelai dan diaduk kembali.

g) Bahan yogurt dimasukkan ke dalam wadah bertutup yang bersih (jenis dan volume sesuai selera), kemudian disimpan pada suhu kamar selama 12 jam.

h) Soy yogurt yang diperoleh dapat digunakan sebagai bibit pada pembuatan yogurt selanjutnya.

i) Soy Yogurt disajikan dengan penambahan madu, jus buah atau bahan tambahan lain sesuai selera.

j) Soy Yogurt dapat disimpan di kulkas hingga 7 hari.

\section{HASIL DAN PEMBAHASAN}

\section{Kegiatan Webinar}

Webinar dengan topik "Natto dan Soy Yogurt: olahan kedelai sebagai makanan bernutrisi di masa pandemi dan peluang usaha rumahan" cukup menarik perhatian bagi berbagai kalangan masyarakat. Hal ini terlihat dari banyaknya masyarakat yang mendaftar kegiatan webinar. Sebanyak 127 orang dari berbagai daerah di Jawa maupun luar Jawa berminat mengikuti webinar, dengan mengisi data di Google Form yang disediakan. Pendaftar terbanyak dengan pendiddikan terakhir SMA (50\%), diikuti S1 (24\%), S2 (21\%) dan S3 (5\%).

Hal ini menunjukkan bahwa topik yang dipilih cocok untuk kondisi saat ini. Sebanyak $47 \%$ peserta sangat setuju dan $53 \%$ peserta webinar setuju dengan pernyataan tersebut.

Namun demikian, pada saat pelaksanaan Webinar hanya 65 orang yang bergabung pada acara Webinar melalui aplikasi Zoom Meeting, sebagaimana terlihat screenshot Webinar pada Gambar 1.

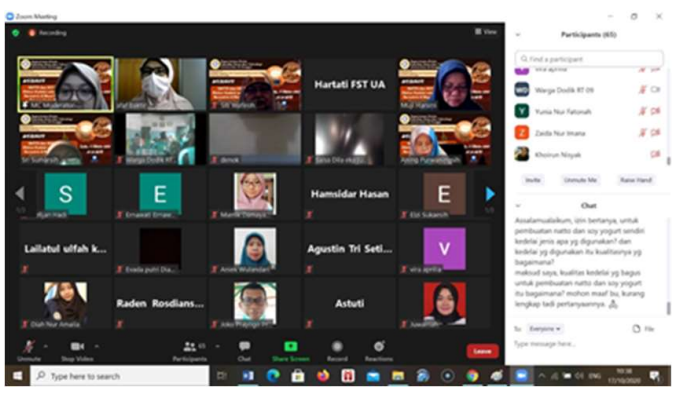

Gambar 1. Peserta Webinar dengan Zoom Meeting

Dengan demikian, hanya 57 orang pendaftar yang dapat bergabung pada acara Webinar melalui aplikasi Zoom Meeting. Sebagian besar pendaftar yang sebagian besar ibu-ibu rumah tangga, mengurungkan diri untuk mengikuti Webinar. Hal ini kemungkinan disebabkan karena banyak pendaftar yang mengalami kesulitan mengakses atau belum mengenal atau belum terbiasa dengan aplikasi Zoom. Hanya pendaftar dari kalangan tertentu, yang memang sudah mengenal atau terbiasa menggunakan aplikasi Zoom, misalnya dari kalangan pendidikan, yang bergabung pada acara Webinar. Hal ini nampak, sebagian besar peserta Webinar yang mengisi darfar hadir (92\%) menghendaki Sertfikat Webinar. Dengan demikian, dapat disimpulkan bahwa kegiatan PKM yang melibatkan berbagai kalangan masyarakat saat ini belum dapat memanfaatkan aplikasi Zoom sepenuhnya.

Walaupun demikian, hampir semua peserta menyatakan bahwa webinar merupakan media yang cocok untuk penyampaian materi PKM pada kondisi pandemi saat ini (Tabel 1).

Pada webinar ini disampaikan materi berjudul "Natto dan Soy Yogurt: Manfaat dan peluang usaha rumahan" oleh Nara Sumber. Pada kesempatan ini juga ditayangkan video pendek "Pembuatan dan penyajian Natto dan Soy Yogurt"

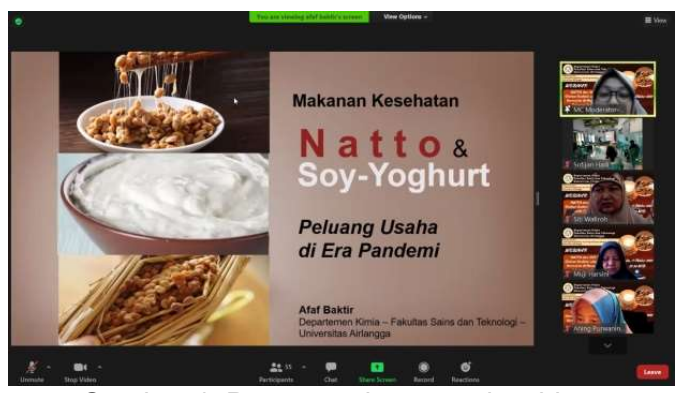

Gambar 4. Penyampaian materi webinar

Peserta webinar yang hadir secara virtual maupun yang hadir di lokasi kegiatan berkesempatan bertanya ke pembicara. Sebanyak $87 \%$ peserta belum pernah mengikuti acara sejenis, sehingga peserta antisias bertanya berbagai hal terkait dengan Natto dan Soy Yogurt, antara lain manfaat, cara pembuatan, serta bahanbahan yang diperlukan untuk pembuatan Natto dan Soy Yogurt. Pada kegiatan webinar ini, peserta yang hadir secara virtual menuliskan pertanyaan pada kolom chat, selanjutnya pertanyaan dibacakan oleh moderator untuk dijawab langsung oleh pembicara.

Di masa pandemi Covid-19 ini, kegiatan PKM juga dilaksanakan dengan melakukan tatap muka dan berkegiatan bersama masyarakat, dengan protokol kesehatan dan jumlah peserta terbatas. Pada kegiatan ini, 15 orang ibu-ibu PKK yang berkenan hadir di lokasi kegiatan berkesempatan mengikuti webinar bersama-sama. 


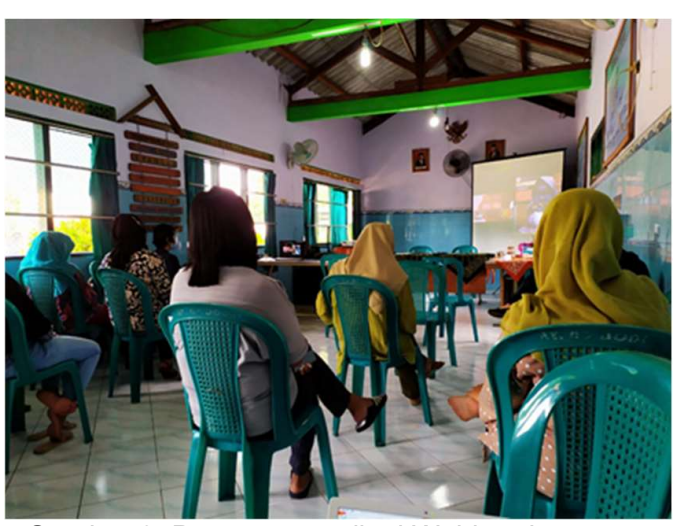

Gambar 3. Peserta mengikuti Webinar bersamasama di lokasi kegiatan

Praktik membuat Natto dan Soy Yogurt

Peserta yang hadir di lokasi kegiatan berkesempatan mempraktikkan beberapa tahapan penting pada pembuatan Natto dan Soy Yogurt.

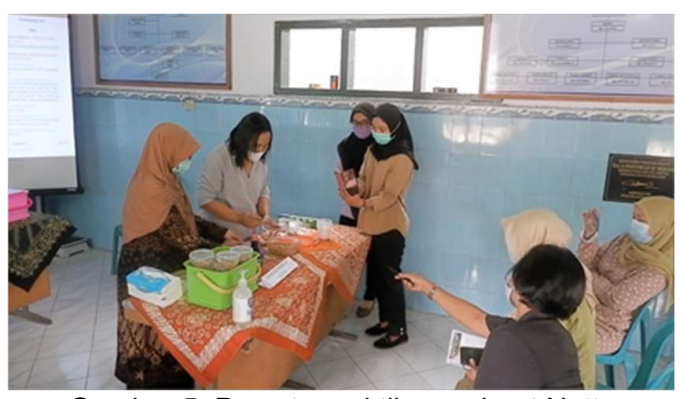

Gambar 5. Peserta praktik membuat Natto

Pada kegiatan ini juga disediakan contoh produk Natto dan Soy Yogurt yang sudah jadi, sehingga peserta dapat mempraktekkan cara penyajian Natto dan Soy Yogurt sehingga siap untuk dikonsumsi. Kedua produk fermentasi tersebut merupakan makanan fungsional atau makanan kesehatan, yang mempunyai rasa tidak enak sehingga tidak semua orang berkenan atau bisa mengkonsumsinya. Oleh karena itu, perlu strategi dan ketrampilan tertentu serta inovasi agar

Tabel 1. Evaluasi Kegiatan makanan kesehatan tersebut menjadi menarik dan enak dikonsumsi.

Peserta yang hadir di lokasi antusias bertanya berbagai hal tentang jenis/ kualitas bahan baku kedelai, jenis/merk dan cara pembelian bibit Natto dan Yogurt, teknis pembuatan dan penyajian, serta manfaat Natto dan Soy Yogurt untuk menjaga kesehatan keluarga pada pandemi Covid-19.

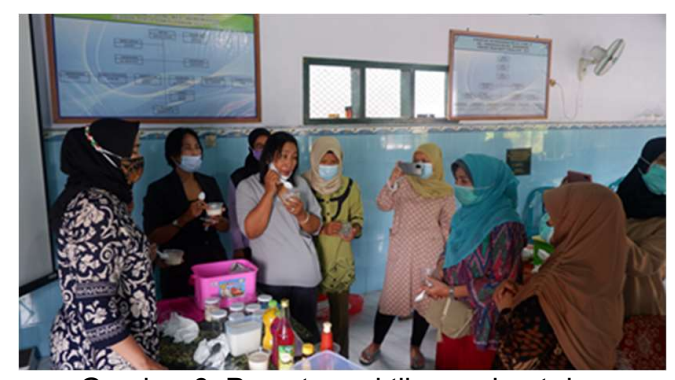

Gambar 6. Peserta praktik membuat dan menyajikan Soy Yogurt

\section{Evaluasi Kegiatan}

Tingkat keberhasilan, kemanfaatan dan keberterimaan masyarakat dari kegiatan PKM ini diketahui dari respon peserta selama mengikuti kegiatan.

Hasil penilaian/ respon peserta kegiatan yang hadir secara virtual maupun yang hadir di lokasi, tercantum pada Tabel 1 dan grafik pada Gambar 7 .

Berdasarkan respon peserta kegiatan, secara umum dapat disimpukan bahwa kegiatan PKM pada kondisi pandemi Covid-19 dapat terlaksana dengan baik melalui kegiatan webinar dan praktik Aplikasi Zoom Meeting dapat digunakan sebagai media kegiatan PKM, walaupun belum bisa menjangkau lapisan masyarakat luas. Materi yang disampaikan Nara sumber sesuai untuk kondisi pandemi saat ini, mudah dipahami, mudah dipraktekkan dan dapat dikembangkan untuk usaha rumahan.

\begin{tabular}{|c|c|c|c|c|c|}
\hline No. & Aspek yang dinilai & \multicolumn{4}{|c|}{ Skor $(\%)$} \\
\hline & & 4 & 3 & 2 & 1 \\
\hline 1. & Kesesuaian topik yang disampaikan untuk kondisi saat ini & 47 & 53 & 0 & 0 \\
\hline 2. & $\begin{array}{l}\text { Kesesuaian media penyampaian materi (zoom dan tatap } \\
\text { muka) dengan kondisi saat ini }\end{array}$ & 45 & 45 & 7 & 2 \\
\hline 3. & Tingkat kemudahan materi untuk dipahami & 27 & 64 & 9 & 0 \\
\hline 4. & Kemanfaatan kegiatan bagi masyarakat & 49 & 44 & 5 & 2 \\
\hline 5. & Kemudahan materi dipraktikan & 33 & 58 & 9 & 0 \\
\hline 6. & $\begin{array}{l}\text { Tingkat kemunkinan materi bisa dikembangkan sebagai } \\
\text { usaha rumahan }\end{array}$ & 36 & 60 & 4 & 0 \\
\hline 7. & Kesempatan peserta untuk mengajukan pertanyaan & 44 & 51 & 5 & 0 \\
\hline 8. & Tanggapan pembicara terhadap pertanyaan peserta & 35 & 60 & 5 & 0 \\
\hline 9. & Tingkat kepakaran Narasumber & 53 & 47 & 0 & 0 \\
\hline 10. & Kelayakan fasilitas kegiatan & 25 & 67 & 7 & 0 \\
\hline
\end{tabular}




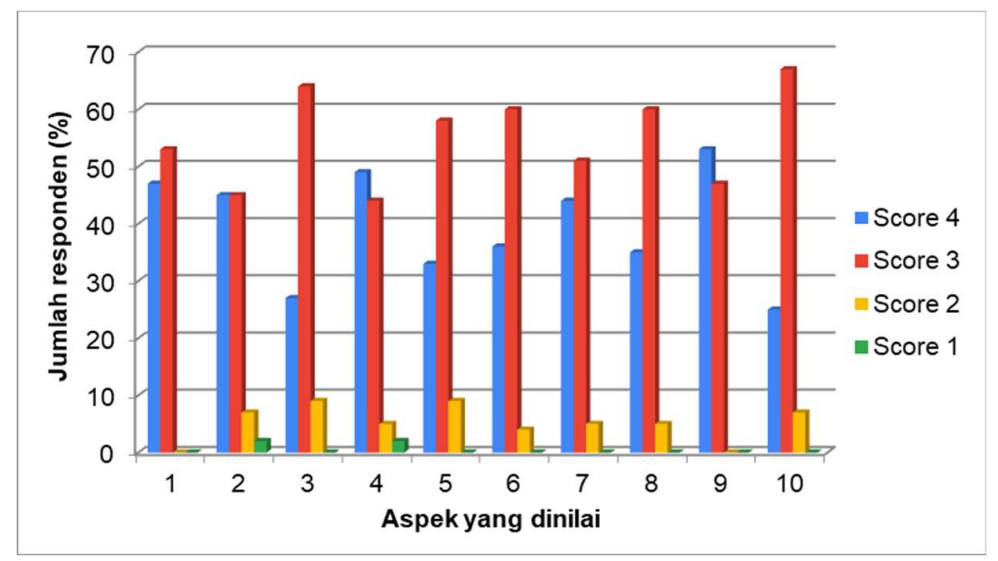

Gambar 7. Grafik evaluasi kegiatan

Setelah mengikuti kegiatan PKM ini, peserta dapat membuat Natto dan Soy Yogurt untuk konsumsi sendiri. Selanjutnya dapat dikembangkan sebagai peluang usaha rumahan untuk mendapatkan penghasilan tambahan.

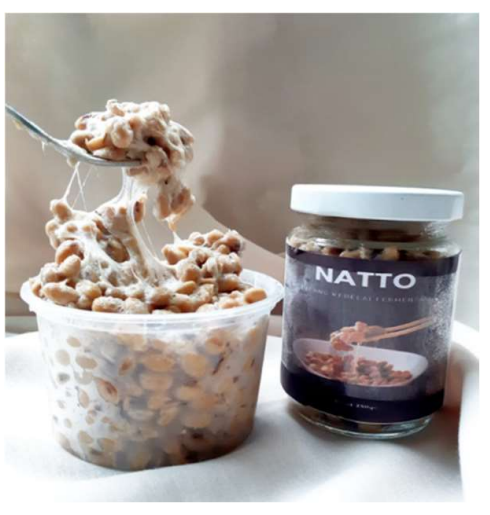

Gambar 8. Produk Natto

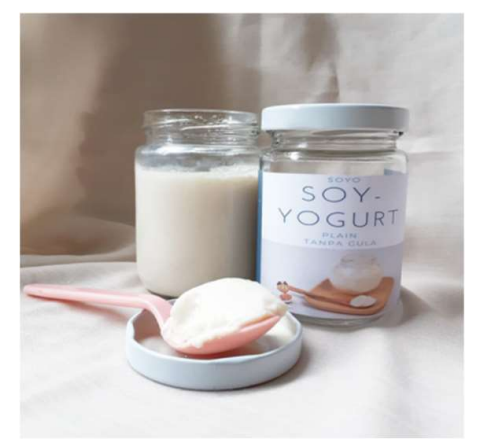

Gambar 9. Produk Soy Yogurt

\section{SIMPULAN DAN SARAN}

\section{Simpulan}

1. Kegiatan PKM pada kondisi pandemi dapat terlaksana dengan baik melalui kegiatan webinar dan praktik.

2. Setelah mengikuti kegiatan webinar dan praktik, peserta dapat membuat Yatto dan Soy Yogurt untuk konsumsi keuarga.

\section{Saran}

Berdasarkan masukan dari peserta, kegiatan perlu dilanjutkan dengan pelatihan cara pembuatan dan pemasaran produk natto dan soy yogurt ke UMKM.

\section{DAFTAR PUSTAKA}

Papp, M. 2014, Learning about Natto, Fermented soybeans, Japan Travel, https://id.japantravel.com/ibaraki/belajar tentang-natto/17370., Diakses pada 28 Maret 2020

Petre, A. 2017, Why Natto Is Super Healthy and Nutritious https://www.healthline.com/nutrition/natto. Diakses pada 28 Maret 2020

Vij, S., Hati, S., Yadav, D. 2011, Biofunctionality of Probiotic Soy Yoghurt. Food and Nutrition Sciences. 2: 502-509, doi:10.4236/fns.2011.25073 